\title{
Conceptual Approaches to Organizational and Methodological Support Systems and Certification of Qualifications
}

\author{
Svetlana Vasilievna Ogneva ${ }^{1}$, Yuri Viktorovich Kopylov ${ }^{2}$ \& Elena Sergeevna Sakharchuk ${ }^{1}$ \\ ${ }^{1}$ Institute of tourism and hospitality (Moscow) (branch) of Federal state, Budgetary Educational institution of \\ Higher Professional education, Russian state University of tourism and service, Russian Federation \\ ${ }^{2}$ Federal state Budgetary Educational institution of Higher Professional education, Russian state University of \\ Tourism and Service, Russian Federation \\ Correspondence: Svetlana Vasilievna Ogneva, Kronstadt Blvd, 32, Moscow, 125485, Russian Federation.
}

Received: December 19, 2014 Accepted: March 25, 2015 Online Published: May 22, 2015

doi:10.5539/ass.v11n14p111 URL: http://dx.doi.org/10.5539/ass.v11n14p111

\begin{abstract}
The problems of legal and organizational-methodical providing of functioning of the national system of assessment and certification of qualifications. The proposals for amending the legislation. Justified the use of standardization for the unification of the content of fundamental organizational and methodical documents of the system of assessment and certification, enhance transparency of the rules and procedures of certification of qualifications. Proposed list of standards for the formation of the national system of assessment and certification of qualifications.
\end{abstract}

Keywords: certification of qualifications, national standard, organizational-methodical maintenance of certification, professional standard, the national system of qualifications, learning outcomes, standardization

\section{Introduction}

To provide the innovative economic development, Russia needs for new personnel in terms of skill level, information technologies handling and adaptability to economic activity in market conditions. According to monitoring data of the Centre of Market Research (Kopylov et al., 2013) of the Institute of Statistical Research and Economics of Knowledge of the National Research University "Higher School of Economics", about 22-24 percent of executives experienced difficulties in 2013 and 2014 due to lack of qualified workers in industry, and 21-19 percent - in the service sector.

Training of labour force of a new quality is under the constant attention of authorities. Special attention is paid to training of personnel for high-tech sectors. The concept of long-term social-economic development of the Russian Federation for a period up to 2020 (Delovoy, 2014) and a number of other documents passed by the Government of Russia provide for the creation of a modern system of continuous education, training and retraining of staff. The necessity of personnel policy improving in Russia is confirmed in Economic Survey of the Russian Federation (Development of professional standards: the lessons of history), prepared in the context of consideration of the question of the accidence of the Russian Federation to the OECD.

Since 1999, marked by the signing by 29 European countries of the document -The Bologna Declaration (Economic surveys OECD Russian Federation), active development of national qualification systems, aimed to regulating of existing diversity of forms of education and training is taking place. The purpose of national qualification systems is to provide the opportunity of forming of multiple ways of learning, leading to the specific qualifications and qualification upgrade as well as clear procedures of the official recognition of qualifications. One of the elements of the national qualifications system is the qualifications certification system, which is the most developed in such counties as: Belgium, Denmark, Estonia, Finland, France, Ireland, the Netherlands, Norway, Portugal, Romania, Slovenia, Spain, Great Britain.

The aim of our research is rationale of conceptual directions in the part of legal, methodical and organizational execution of the system of certification of qualifications.

\section{Methods}

The operation of the qualification certification system includes development of requirements for the object of certification, legal, organizational and methodological support, the structure of which is the main subject of the 
essay. The research is conducted on the basis of analysis and comparing of Russian and international systems of personnel certification and of analysis of the Russian legislation in terms of establishing of qualification requirements and introduction of qualification certification.

The research covers the following issues: concepts apparatus, objectives and legal basis of formation of qualifications certification system, the role of professional standards and methodical support for the professional standards development, methodical support and experience in the development and functioning of qualifications certification systems, the possibility of unification of methodical documents by applying standardization, creation and discussion of the results, formulating of conclusions and proposals.

The research has allowed not only to formulate basic rules of the system of standards for designing of the qualifications certification system, but also to found directions for further work on the formation of the national qualifications system.

In the research empirical research methods (comparison, description) as well as logical methods and techniques of research (analysis, synthesis, system approach) were used.

\section{Results}

\subsection{Professional Standards as the Basis for a System of Certification of Qualifications}

External independent assessment - certification of professional qualifications for the assessment of the results of both formal and informal education was proposed in 2009 by the Russian Union of Industrialists and Entrepreneurs. Main purpose of the system of the assessment and qualification certification is objective, independent, recognized by all the professional community assessment of compliance of competences staff, graduates and other categories of population, trained in various forms (hereinafter - worker), confirmation of the worker's ability to perform specific forms of labour activity regardless to the place, time and method of obtaining qualifications. Qualification certificate must confirm mastering by the applicant of certain competencies for performing specific work.

The key factor in every certification system is identification (and, in the future, following) of requirements to the object of certification, in this case - requirements to the qualification of worker, i.e. to the quality of training, his(her) knowledge, skills, abilities, applicable to a particular position (profession). That first needs to develop professional standards, compliance with which must include independent assessment of qualifications certification, and eventually national system of qualification certification must be formed, as a part of national system of qualification certification (Final report on the results of the expert work on actual problems of socio-economic strategy of Russia for the period till 2020). In Russia professional standards are actively being developed with the regulation of this process by the state. The term "Professional standard" is containing in the Labour Code, rules of development, adoption and application (GOST R 52807- 2007) of professional standard established by the Government of Russia (GOST R 53697-2009) and guidelines for their development (GOST R 54795-2011/ISO/DIS 9712) are approved by the Ministry of Labour of Russia. It follows that Russia's system of government documents established legal and methodological framework of development and application of professional standards.

The organizational structure for development of the professional standards is being formed and concrete steps are made. The development of professional standards is under the control of the President of the Russia, so the President of Russian Federation created a social structure - National Council for professional qualifications (The decree of the President of the Russian Federation from 16.04.2014 \# 249). The Council is consultative body formed to consider matters relating to the establishment and development of the system of professional qualifications in Russia. Its responsibilities include expertise, development, preparation of proposals on improvement of professional standards. It is assumed that professional standards will replace qualifying characteristics and tariff-qualification characteristics of professions and positions, i.e. the formed in the Soviet era system of the regulating documents on labour is changing its format and content. For the organizing of the activity Councils for professional qualifications are being formed in the sectors. One of their functions is development, updating and organizing of application of professional standards.

\subsection{The Legal Basis of the System of Certification of Qualifications}

For many spheres of economic activity, where have been already developed and approved professional standards, the basis for implementing of assessment and qualification certification systems is established. There is some lagging of regulatory process of creating of assessment and certification systems from the process of development of professional standards. 
Analysis of Russian and international experience of creation and functioning of qualification certification systems in the field of tourism and service showed that in this area we can distinguish four main approaches to the forming of assessment and qualification certification systems. The systems can be based on purely corporate mechanisms and procedures, on strict government regulation, on state-private partnership, on voluntary establishing of personnel certification systems according to the rules and regulation of the law (Kopylov, 2013)

Creating of the national qualification certification system as an integral part of the National qualification system requires legislative regulation. Today the starting point of forming of qualification certification system in Russia is the regulation dated 2009 on assessment and qualification certification of graduates, educational institutions of professional education and other categories of citizens, who took professional education in different forms (GOST R ISO 11484-2014). The regulation is proposed by the Russian Union of Industrialists and Entrepreneurs and the Ministry of Education and Science of Russia. In the document are proposed approaches to organizational building of qualifications certification system as a single national one, for which legal status of the document is not sufficient. According to the Russian legislation, the legal status of the qualifications certification system is validated: by a Federal law of Russian Federation, if in relation to regulated professions, which are very important for society involving activity related with execution of works and rendering of services, which may affect the health and safety of citizens, national security, etc., qualifications certification will be required; or by the document of the regulator which coordinates activity of qualifications certification in Russia. But in any case main provisions of qualifications certification should be legislated.

\subsection{Legal Confirmation of the Conceptual Apparatus}

Absence of a common conceptual apparatus at the legislative level has led to appearance of regional qualifications certification systems, voluntary personnel certification systems (Ogneva \& Kopylov, 2013), with their own professional standards, rules and procedures. One of the tasks solved by formation of national qualifications system is the legal recognition of general definitions such as qualifications certification, qualification certificate, center of assessment and qualifications certification, national, regional, sectoral agency of qualifications development, assessment and qualifications certification expert etc.

In this direction two approaches can be proposed: adoption of the Federal law, devoted to the issue of qualifications certification and/or adopting of amendments to the Labour Code (Shchur, 2012).

\subsection{Normative-Methodical Maintenance of Certification Qualifications}

Creating of general rules of qualifications certification is the next task, solving which will allow to develop sectoral certification systems with their own characteristics in questions of assessment. This task can be solved by creating of the complex of national standards: SSQA - system of standards of qualifications assessment. The necessity of development of the complex of standards was claimed in an article published in 2013 (Ogneva \& Kopylov, 2013).

This system may include all the provisions from terminology to the rules of sectoral systems, especially as a precedent of development of national standards in the sphere of qualification certification already exists in the field of non-destructive testing and project management, for example:

- GOST R 54795-2011 "Non-destructive testing. Qualification and certification of personnel. General principles" sets requirements for the qualification and the order of certification of the personnel, participating in non-destructive testing;

- GOST R 53697-2009 (ISO/TS 181173:2005) Non-destructive testing. General terms and definitions;

- GOST R 52807-2007 Guidance for assessment of project management personnel competency sets requirements for the project managers' competence and requirements for personnel conducting assessment, i.e. provides basis of the professional compliance. The standard is developed with due regard for the requirements of the standard "Global Performance Based Standards for Project Management Personnel. Performance Based Competency Standards for Global Level 1 and 2 Project Managers" (GPBSPMP);

- GOST R ISO 11484-2014 Steel products. System of estimation the employer of qualification of the personnel which is carrying out nondestructive control. This standard is identical to the international standard ISO 11484: 2009 Steel products - Employer's qualification system for nondestructive testing (NDT) personnel.

The fundamental system of standards of assessment and qualification certification may include the following standards:

Terms and definitions

General rules of the assessment and certification of qualifications 
Requirements for assessment and qualifications certification experts

Rules of payment for assessment work and qualifications certification work.

Requirements for assessment and qualifications certification organs and the order of their accreditation.

Requirements for expert-methodological center

Qualification assessment methods

Rules of conducting of the registry of qualifications certification system

Requirements for qualification certificate

Requirements for the formation and organization of the activity of appeals commissions

Requirements to the regional agencies of qualifications development

Control of activity of the assessment and qualifications certification organs

Next, in the form of national standards, specification of general requirements at sectoral level - level of type of labour activity, can be made. This is not interfere with participation in realization of assessment and qualifications certification system of different parties including ministries and other government structures, unions of employers and educational system. For example, "Tourism services. Rules of assessment and qualifications certification. General requirements" etc.

Creation of the system of standards in the field of assessment and qualifications certification will allow to form documentally national system of assessment of qualifications, thus facilitating its implementation both as a mandatory system for certain types of activities, and as a voluntary one. Organizing of development of national standards can be provided by Technical Standardization Committee "Assessment and certification of qualifications" at the Ministry of Labour and Social Protection of Russian Federation or by Research Institute of Labour and Social Insurance of Ministry of Labour of Russian Federation, creating of which would allow to regulate activities for development of documents of assessment and qualifications certification system.

\section{Discussion}

The beginning of development of personnel certification, which later evolved into a qualifications certification, the emergence of the terms "personnel certification" and "professional standard" were related with the adoption of the program of social reforms in Russian Federation for the period 1996-2000. (Resolution of the Government of the Russian Federation from 26.02.97 \# 222). Personnel certification was developed as a voluntary procedure. With the establishment in Russia of the obligatory certification of products and services a separate line stood up - certification of experts. The experts certification system was methodically elaborated in terms of its organization, procedure and other processes. Requirements for the competence of experts are stated in internal documents of the system. A similar approach existed in other certification systems. And only now these requirements are being tried to state in professional standards.

A fundamentally new approach to qualification certification was proposed by the Russian Union of Industrial and Entrepreneurs (RSPP), which was supported by the Ministry of education and science of the Russian Federation. Both structures have signed on 27 June 2007 agreement on cooperation in implementation of the following works: development of the national system of qualifications, establishment of professional standards, establishment of state standards of the professional education, establishment of an independent system of education quality assessment and qualifications certification, development of modern innovative educational programs. The initiators of the agreement were RSPP as representative of business interests in improvement of quality of human resources, and the Ministry of education and science as a regulator of the training of human resources for the national economy.

RSPP in 2009 has initiated the establishment with the approval of the Ministry of education and science of a system of independent assessment of quality of professional education (24, The regulations on the formation of a system of independent quality assessment of vocational education, 2009), differing from the previous one, which had been implemented by the Ministry of education and science, with its comprehensive approach. RSPP was also the initiator of establishment of the National Agency of the Development of Qualifications (NARK). Functions of this organization are broad and aimed at establishing of the National system of qualifications. First of all it was necessary to create modern regulatory requirements for professions - professional standards. From 2007 to 2013 the structure coordinated the development of professional standards. The history of the development of professional standards is well described in several publications (Shchur \& Shur-Truchanowicz, 2012), (Shur-Truchanowicz \& Shur, 2010). It can be found on the website of Center for research in Economics 
and law. Professional standards were considered and accepted at meetings of the public State council, which had been formed of representatives of business and educational system, because the standards are developed by the business and their requirements to competences are the basis for the state educational standards and educational programs. At the same time the system of the assessment and certification of qualifications of graduates, educational institutions of professional education, other categories of citizens, who had professional training in various forms, was being established. On a competitive basis within the framework of the Federal Program of Development of Education for 2011-2015 (Regulation of the RF Government dated 07.02.2011 \# 61) a development of sectoral systems of assessment and certification had been conducted, the systems were approbated. Were elaborated: organizational structure of the systems, documentary, material, methodical and informational support.

It is offered on the ongoing system of evaluation and certification that all functions might be assigned for the next participants: Public-state council, the base organization (NARK), expert-methodical centers, centers of assessment and certification, with functioning Appeal committees and applicants attached to them. Public-state council coordinates the activity of the system, determines the directions of organizational development, approve the organizational and methodical documents and monitors its activities. Basic organization creates organizational and technical support of activities of the Public-state council and the whole system. In fact, the basic organization is the technical organizer of the system of assessment and qualifications certification. The functions of other participants are obvious from the names. The analysis of sectoral systems shows that organizationally systems differ and not always follow the recommendations of the RSPP and NARK. The situation is understandable and predictable. Russia with its vast territory, with specific character of businesses allocation, still remaining from Soviet times, requires approaches that along with centralization, would give regional and sectoral freedom in the establishment of certification systems.

The Ministry of Labour of Russia proposed a variant of the system in which priority is given to the organizers of the independent qualification assessment: all-Russian associations of employers, all-Russian industrial association of employers, Professional non-profit organizations, national and interregional trade unions, their associations. For now this is only a variant discussed with all concerned parties. This situation has led us to the results presented in this article. The essence of these proposals is in increasing of the level of adoption of normative and methodical documents regulating the activities of the certification system, from branch and departmental level to the Federal level, from methodical recommendations and regulations to national standards. Undoubtedly, a separate working papers, assessment tests can be developed in the certification system, but the basic documents of the system of assessment and certification must be approved at the Federal level in the form of national standards. For efficient functioning of the system in our opinion a set of standards - a System of standards of assessment and qualifications certification - SSOC must be developed.

\section{Conclusion}

This study shows the necessity of legal support of qualification certification, thus, at this stage of its formation it is enough to make amendments to the Labour Code and to define of legislative list of regulated professions. The whole system of organizational-methodological provision of assessment and certification system can be standardized. In the study practicability of establishing of system of national standards in sphere of assessment and qualification certification is proved. The proposed set of documents is preliminary and must be corrected at a deeper filling of content of proposed system of standards. A standardized approach to the forming of assessment and qualification certification systems lets us to organize assessing and certifying activity, to unify the system of organizational-methodological documents, to improve transparency of rules and procedures of certification, to make them accessible for all categories of workers, to create conditions for recognition of procedures and results of the assessment by the world, and primarily by the European community.

\section{References}

Delovoy klimat v real'nom sektore v sfere uslug Rossii vo II kvartale (p. 32). (2014). M.: NRI HSE.

Development of professional standards: the lessons of history. Center for economic development and certification. Retrieved from http://profiok.com/about/news/detail.php?ID=1633\&print=y

Economic surveys OECD Russian Federation. (2014 January). The main conclusions and recommendations. Retrieved from http://oecd.org/eco/surveys/Overview_RUSSIARus_2013.pdf

Final report on the results of the expert work on actual problems of socio-economic strategy of Russia for the period till 2020. Strategy 2020: New growth model - a new social policy.

GOST R 52807-2007. Guidance for assessment of project management personnel competency. 
GOST R 53697-2009 (ISO/TS 181173:2005). Non-destructive testing. General terms and definitions.

GOST R 54795-2011/ISO/DIS 9712. Non-destructive testing. Qualification and certification of personnel. General principles.

GOST R ISO 11484-2014 Steel products. System of estimation by the employer of qualification of the personnel carrying out nondestructive control.

Kopylov, Y. V., Ogneva, S. V., Krivosheeva, T. M., Zaitseva, N. A., Dosenko, S. B., Makeeva, D. R., ... Belyansky, V. P. (2013). Analysis of international, Russian and foreign experience of conducting an independent evaluation of the quality of professional education in the sphere of tourism with the aim of developing mechanisms of its use in the Russian. The research report (Federal Agency for tourism).

Labour Code from 30.12. 2001 \# 197-FZ (as amended 04.11.2014).

Ogneva, S. V. (2012). Sotsial'no-economicheskiy mekhanizm formirovaniya I obespecheniya kachestva rabochey sily turistskoy industrii (pp. 212-216). Monograph: FSBEI of HPE RSUTS.

Ogneva, S. V., \& Kopylov, Y. V. (2013). Kontseptual'nye podkhody k formirovaniyu sistem otsenki i sertifikatsii kvalifikatsiy $v$ turizme (pp. 24-28). Sbornik dokladov I tezisov Itogovoy vserossiyskoy konferentsii Sovershenstvovanie modeli ezhegodnogo konkursa Rosobrnadzora Sistemy kachestva podgotovki vypusknikov obrazovatel'nykh organizatsiy vysshego professional'nogo obrazovaniya, part 2 - Moscow State University of Economics, Statistics and Informatics. M.

Order of the Ministry of labour of Russia from 12.04.2013 \# 147 n. On approval of the Layout of a professional standard. Rossiyskaya Gazeta, \# 119, 05.06.2013

Order of the Ministry of Russia dated 29.04.2013 \# $170 \mathrm{n}$. On approval of methodological recommendations on the development of professional standard. Bulletin of labor and social legislation of the Russian Federation.

Regulation of the RF Government dated 07.02.2011 \# 61 (as amended on 26.11.2012). On the Federal target program of education development for 2011-2015. Collected legislation of the Russian Federation.

Regulation of the RF Government dated 22.01.2013 \# 23 On the Rules of development, approval and application of professional standards. Collected legislation of the Russian Federation, p. 293.

Regulations on the assessment and certification of qualifications of graduates of educational institutions of professional education, and other categories of citizens, who have professional training in various forms. Approved by the Minister of education and science A. A. Fursenko, 31 July 2009 \# AF-317/03 and President of RSPP A. N. Shokhin July 27, 2009.

Resolution of the Government of the Russian Federation from 26.02.97 \# 222. About the Program of social reforms in the Russian Federation for the period 1996-2000.

Shchur, D. L., \& Shur-Truchanowicz, L. C. (2012). Professional standards: the past and future of the national system of competences and prospects for trade. Trade law, 11.

Shur-Truchanowicz, L. C., \& Shur, D. L. (2010) Research: Professional standards in the Russian Federation: characteristics of the national system of professional standards. Center for research in Economics and law. Retrieved from http://cisep.ru/upload/Professional\%20standards\%202010\%20NIR.pdf

The Bologna Declaration of 19 June 1999. Joint declaration of the European Ministers of Education.

The decree of the President of the Russian Federation from 16.04.2014 \# 249. On the National Council under the President of the Russian Federation for professional qualifications (together with the Regulation on the National Council under the President of the Russian Federation for professional qualifications).

The order of the RF Government dated 17.11.2008 \# 1662-p (redaction dated 08.08.2009). O Kontseptsii dolgosrochnogo sotsialno-ekonomicheskogo razvitia Rossiyskoy Federatsii na period do 2020 goda.

The regulations on the formation of a system of independent quality assessment of vocational education (Approved by A. A. Fursenko \& A. N. Shokhin).

\section{Copyrights}

Copyright for this article is retained by the author(s), with first publication rights granted to the journal.

This is an open-access article distributed under the terms and conditions of the Creative Commons Attribution license (http://creativecommons.org/licenses/by/3.0/). 